\title{
Occurrence and genetic typing of infectious hematopoietic necrosis virus in Kamchatka, Russia
}

\author{
Svetlana L. Rudakova ${ }^{1, *}$, Gael Kurath ${ }^{2}$, Elena V. Bochkova ${ }^{1}$ \\ ${ }^{1}$ Kamchatka Research Institute of Fisheries and Oceanography (KamchatNIRO), Naberezhnaya 18, \\ Petropavlovsk-Kamchatskii 683000, Russia \\ ${ }^{2}$ USGS Western Fisheries Research Center, 6505 NE 65th Street, Seattle, Washington 98115, USA
}

\begin{abstract}
Infectious hematopoietic necrosis virus (IHNV) is a well known rhabdoviral pathogen of salmonid fish in North America that has become established in Asia and Europe. On the Pacific coast of Russia, IHNV was first detected in hatchery sockeye from the Kamchatka Peninsula in 2001. Results of virological examinations of over 10000 wild and cultured salmonid fish from Kamchatka during 1996 to 2005 revealed IHNV in several sockeye salmon Oncorhynchus nerka populations. The virus was isolated from spawning adults and from juveniles undergoing epidemics in both hatchery and wild sockeye populations from the Bolshaya watershed. No virus was detected in 2 other watersheds, or in species other than sockeye salmon. Genetic typing of 8 virus isolates by sequence analysis of partial glycoprotein and nucleocapsid genes revealed that they were genetically homogeneous and fell within the U genogroup of IHNV. In phylogenetic analyses, the Russian IHNV sequences were indistinguishable from the sequences of North American U genogroup isolates that occur throughout Alaska, British Columbia, Washington, and Oregon. The high similarity, and in some cases identity, between Russian and North American IHNV isolates suggests virus transmission or exposure to a common viral reservoir in the North Pacific Ocean.
\end{abstract}

KEY WORDS: Fish virus $\cdot$ IHNV $\cdot$ Sockeye salmon $\cdot$ Russia $\cdot$ Virus typing $\cdot$ Rhabdovirus $\cdot$ Infectious hematopoietic necrosis virus

\section{INTRODUCTION}

Infectious hematopoietic necrosis (IHN; Amend et al. 1969) is an economically significant disease caused by a rhabdovirus (IHNV) in Pacific salmon Oncorhynchus spp., Atlantic salmon Salmo salar, and rainbow/steelhead trout O. mykiss (Wolf 1988, Bootland \& Leong 1999). The disease was first observed in cultured sockeye salmon $O$. nerka in western North America (Rucker et al. 1953, Watson et al. 1954), and the first report of IHNV isolation in cell culture was by Wingfield et al. (1969). Economic losses from IHNV result directly from fish mortality, and indirectly from regulations restricting the movement of IHNV-infected fish or the destruction of infected fish stocks to control the spread of the virus.
In North America, IHNV is currently endemic throughout the Pacific Northwest, where it occurs in multiple Pacific salmon and trout species. An IHNV genetic typing system has been developed based on phylogenetic analysis of the 303 nucleotide (nt) 'midG' region within the viral glycoprotein (G) gene (Emmenegger et al. 2000, Troyer et al. 2000, Emmenegger \& Kurath 2002, Garver et al. 2003, Kurath et al. 2003, Troyer \& Kurath 2003). This system has revealed 3 major IHNV genogroups in North America, designated $\mathrm{U}, \mathrm{M}$, and $\mathrm{L}$ to correlate with their occurrence in the upper, middle, and lower portions of the virus geographic range (Kurath et al. 2003). The resolution of IHNV into these genogroups has recently been confirmed by analyses of a second genetic region, the ' 5 ' $\mathrm{N}$ ', which is a 412 nt sequence 
near the $5^{\prime}$ end of the viral nucleocapsid $(\mathrm{N})$ gene (Garver et al. 2003, Kurath et al. 2005). A set of 37 North American IHNV isolates has been selected to represent all genogroups and sub-genogroups currently known, and their midG and $5{ }^{\prime} \mathrm{N}$ sequences comprise the GB37 data set for IHNV phylogenetic analyses (Kurath et al. 2005).

Although originally endemic to North America, IHN also occurs in Asia and Europe, where it is thought to have been spread during the 1960s and 1980s, respectively, via transport of infected fish eggs or fry from North America (Sano et al. 1977, Bovo et al. 1987). In Russia, IHN was confirmed from rainbow trout in an experimental hatchery near Moscow in 2000 (I. Shchelkunov pers. comm.). This virus had never been detected on the Pacific coast of Russia until it was isolated among adult sockeye salmon on the Kamchatka Peninsula in 2001 (Rudakova \& Bochkova 2005). In Kamchatka, 5 fish hatcheries rear several species of Pacific salmon for release into rivers and streams. This report describes virological testing, IHNV isolations, and the first genetic characterizations of IHNV from cultured and wild Pacific salmon in Eastern Russia.

\section{MATERIALS AND METHODS}

Virological sampling and diagnosis of IHNV. A total of 7697 cultured and 2933 wild salmonid fish from Kamchatka were examined during 1996 to 2005 (Tables $1 \&$ 2). Fish species sampled were Salvelinus malma and Pacific salmon Oncorhynchus spp.: sockeye salmon $O$. nerka, chum salmon O. keta, pink salmon $O$. gorbuscha, chinook salmon $O$. tschawytscha, and coho salmon $O$. kisutch. The fish were either caught on their natural spawning grounds by netting or collected from holding ponds used to maintain spawning adults or fry at the salmon hatcheries.

Ovarian fluid and pools of kidney and spleen from adult fish (5 fish per pool), or whole fry or viscera of juvenile fish (5 fish per pool), were collected and transported to the laboratory on ice as described by LaPatra (1994). In 2005, ovarian fluid and kidney/ spleen specimens from adult sockeye were collected from individual fish. Ovarian fluid was centrifuged without dilution. Tissue samples were homogenized in a mortar with quartz sand, and minimal essential medium (MEM-0) was added to equal a 1:10 dilution $(\mathrm{w} / \mathrm{v})$. Dilutions were centrifuged at $6000 \times g$ for

Table 1. Occurrence of IHNV in Kamchatka hatchery salmon. Bold italics indicate IHNV positive populations, with viral prevalences as described in text. nt: not tested for virus, fnc: fish not cultured

\begin{tabular}{|c|c|c|c|c|c|c|c|c|c|c|c|}
\hline \multirow{2}{*}{$\begin{array}{l}\text { Hatchery } \\
\text { site }\end{array}$} & \multirow[t]{2}{*}{ Fish stock } & \multicolumn{10}{|c|}{ Number of fish examined each year } \\
\hline & & 1996 & 1997 & 1998 & 1999 & 2000 & 2001 & 2002 & 2003 & 2004 & 2005 \\
\hline \multicolumn{12}{|c|}{ Bolshaya River watershed } \\
\hline \multirow{4}{*}{ Malkinskiy } & Sockeye fry & 60 & 60 & 60 & 120 & 120 & 120 & 170 & 230 & 111 & 175 \\
\hline & Sockeye adult & nt & nt & nt & $\mathrm{nt}$ & 30 & 30 & 185 & 65 & 60 & 60 \\
\hline & Chinook fry & 60 & 15 & 60 & 120 & 120 & 120 & 60 & 60 & 30 & 30 \\
\hline & Chinook adult & $\mathrm{nt}$ & nt & $\mathrm{nt}$ & $\mathrm{nt}$ & 27 & 20 & 30 & 30 & 30 & 30 \\
\hline \multirow[t]{4}{*}{ Ozerki } & Sockeye fry & 60 & 60 & 60 & 60 & 120 & nt & 135 & 120 & 235 & 100 \\
\hline & Sockeye adult & nt & nt & nt & nt & 15 & 30 & 30 & 30 & 90 & 90 \\
\hline & Chum fry & 60 & 60 & 60 & 60 & 60 & nt & 60 & 90 & 90 & 60 \\
\hline & Chum adult & nt & nt & nt & nt & 20 & 30 & 30 & 30 & 30 & 30 \\
\hline \multicolumn{12}{|c|}{ Paratunka River watershed } \\
\hline \multirow[t]{3}{*}{ Paratunskiy } & Chum fry & 60 & 60 & 60 & 120 & 120 & 120 & 60 & 60 & 90 & 30 \\
\hline & Chum adult & nt & nt & nt & nt & 15 & 20 & 20 & 30 & 30 & 30 \\
\hline & Coho fry & fnc & fnc & fnc & fnc & fnc & 120 & 60 & fnc & fnc & fnc \\
\hline \multirow[t]{4}{*}{ Viljuskiy } & Chum fry & 60 & nt & nt & 60 & 60 & 90 & 60 & 90 & 90 & 30 \\
\hline & Chum adult & nt & nt & nt & nt & nt & nt & 30 & 30 & 30 & 30 \\
\hline & Coho fry & fnc & fnc & fnc & fnc & fnc & 30 & 60 & 90 & 90 & nt \\
\hline & Coho adult & nt & nt & nt & nt & nt & nt & 30 & 30 & 19 & nt \\
\hline \multicolumn{12}{|c|}{ Avacha River watershed } \\
\hline \multirow[t]{3}{*}{ Ketkino } & Chum fry & 60 & 60 & 120 & 120 & 120 & 90 & 90 & 90 & 90 & 30 \\
\hline & Chum adult & nt & nt & $\mathrm{nt}$ & $\mathrm{nt}$ & nt & 30 & 30 & 30 & 30 & 30 \\
\hline & Sockeye fry & fnc & fnc & fnc & 60 & fnc & fnc & fnc & fnc & fnc & fnc \\
\hline
\end{tabular}


Table 2. Occurrence of IHNV in Kamchatka wild salmon

\begin{tabular}{|c|c|c|c|}
\hline Site & $\begin{array}{l}\text { Host and } \\
\text { life stage }\end{array}$ & $\begin{array}{l}\text { Years tested } \\
\text { (no. fish tested each year) }\end{array}$ & $\begin{array}{l}\text { Years IHNV positive } \\
\text { (\% prevalence) }\end{array}$ \\
\hline \multicolumn{4}{|c|}{ Bolshaya River watershed } \\
\hline $\begin{array}{l}\text { Mouth of } \\
\text { Bolshaya River }\end{array}$ & $\begin{array}{l}\text { Chum fry } \\
\text { Pink fry } \\
\text { Pink adult } \\
\text { Coho fry } \\
\text { Coho adult }\end{array}$ & $\begin{array}{l}2003(60), 2004(22), 2005(30) \\
2003(60), 2005(30) \\
2005(30) \\
2003(42), 2005(30) \\
2005(30)\end{array}$ & $\begin{array}{l}\text { None } \\
\text { None } \\
\text { None } \\
\text { None } \\
\text { None }\end{array}$ \\
\hline Kluchovka River & $\begin{array}{l}\text { Sockeye fry } \\
\text { Sockeye adult } \\
\text { Salvelinus malma fry } \\
\text { Coho fry }\end{array}$ & $\begin{array}{l}2001(30), 2002(30), 2003(135) \\
2005(6) \\
1997(30), 2001(30), 2002(30), 2003(5), 2005(30) \\
1998(30), 2001(18), 2002(30), 2003(50), 2005(30)\end{array}$ & $\begin{array}{l}\text { None } \\
\text { None } \\
\text { None } \\
\text { None }\end{array}$ \\
\hline $\begin{array}{l}\text { Ganalskiy Vahtang } \\
\text { River }\end{array}$ & Sockeye adult & 2000 (20), 2002 (19), 2005 (21) & $2002(75)$ \\
\hline Domashniy stream & $\begin{array}{l}\text { Sockeye adult } \\
\text { Sockeye fry }\end{array}$ & $\begin{array}{l}2002(13), 2003(30) \\
2003(30), 2004(30), 2005(20)\end{array}$ & $\begin{array}{l}2002(67), 2003(100) \\
\text { None }\end{array}$ \\
\hline Lake Nachikinskoe & $\begin{array}{l}\text { Sockeye adult } \\
\text { Sockeye fry }\end{array}$ & $\begin{array}{l}2003(40), 2004(30), 2005(60) \\
2003(30), 2004(80), 2005(60)\end{array}$ & $\begin{array}{l}2003(100), 2004(67) \\
2005(100) \\
2003(13)\end{array}$ \\
\hline Plotnikova River & $\begin{array}{l}\text { Sockeye adult } \\
\text { Sockeye fry } \\
\text { Coho fry } \\
\text { Chum fry }\end{array}$ & $\begin{array}{l}1998(15), 2001(7), 2002(10) \\
2003(60) \\
1998(20) \\
1998(20)\end{array}$ & $\begin{array}{l}\text { None } \\
\text { None } \\
\text { None }\end{array}$ \\
\hline \multicolumn{4}{|c|}{ Paratunka River watershed } \\
\hline Paratunka River & $\begin{array}{l}\text { Sockeye fry } \\
\text { Sockeye adult } \\
\text { Chum fry } \\
\text { Chum adult } \\
\text { Coho fry } \\
\text { Coho adult }\end{array}$ & $\begin{array}{l}2002(60), 2003(30), 2004(30) \\
2004(7) \\
2001(80), 2003(60), 2004(30) \\
1999(20), 2004(30) \\
1997(30), 2001(19), 2003(90), 2004(30) \\
1999(20), 2000(20), 2003(30), 2004(30)\end{array}$ & $\begin{array}{l}\text { None } \\
\text { None } \\
\text { None } \\
\text { None } \\
\text { None } \\
\text { None }\end{array}$ \\
\hline Lake Bolshoy Viljuy & Coho adult & 1999 (20), 2001 (15), 2002 (7), 2003 (8), 2004 (23) & None \\
\hline \multicolumn{4}{|c|}{ Avacha River watershed } \\
\hline River Avacha & $\begin{array}{l}\text { Chum fry } \\
\text { Chum adult } \\
\text { Coho fry } \\
\text { Coho adult } \\
\text { Sockeye fry } \\
\text { Sockeye adult } \\
\text { Pink adult } \\
\text { S. malma fry } \\
\text { S. malma adult }\end{array}$ & $\begin{array}{l}2001(30), 2002(60), 2003(60), 2004(30) \\
1998(20), 1999(30), 2000(15), 2001(15), \\
2002(30), 2004(30) \\
2000(12), 2001(59), 2002(30), 2004(30) \\
1998(20), 1999(20), 2000(15), 2002(30), \\
2003(8), 2004(30) \\
2002(60) \\
2000(10), 2002(17), 2004(30) \\
2001(25), 2004(30) \\
1997(30) \\
1997(10), 1999(10), 2000(5), 2004(10)\end{array}$ & $\begin{array}{l}\text { None } \\
\text { None } \\
\text { None } \\
\text { None } \\
\text { None } \\
\text { None }\end{array}$ \\
\hline
\end{tabular}

$20 \mathrm{~min}$. Serial $\log _{10}$ dilutions of supernatant for each pool were prepared with minimal essential medium supplemented with $10 \%$ fetal calf serum (MEM-10) and used to inoculate chinook salmon embryo (CHSE214) and epithelioma papulosum cyprini (EPC) cell lines (Fijan et al. 1983) as described by Fried (1984). For each sample, 3 serial dilutions $\left(10^{-1}, 10^{-2}, 10^{-3}\right)$ were each added to 4 wells of a 96 -well plate containing confluent cell monolayers. Cell cultures were incubated at $15^{\circ} \mathrm{C}$, and tissue culture infective doses
$\left(\mathrm{TCID}_{50}\right)$ were determined using the method of Reed \& Muench as described by Musselius (1983).

The appearance of rounded and granular cells in grape-like clusters within the inoculated cell lines was indicative of cytopathic effect (CPE) induced by IHNV (Meyers 2000). Virus was identified as IHNV by serum neutralization assays as described by LaPatra (1994), using a rabbit antiserum to IHNV provided by J. Kaufman (Oregon Department of Fish and Wildlife, Corvallis, OR, USA). When IHNV-infected cell mono- 
layers were almost destroyed, supernatant containing the virus was harvested and frozen at $-70^{\circ} \mathrm{C}$ or lyophilized for long-term storage. This was done after the second or third passage of virus on EPC or CHSE-214 cell lines.

Nomenclature for individual virus isolates was designed to indicate the site of isolation (Ryb, Rybnoe; $\mathrm{MH}$, Malkinskiy Hatchery; OH, Ozerki Hatchery; LN, Lake Nachikinskoe), the last 2 digits of the year of isolation $(20 X X)$, host species $(T$, rainbow trout; $S$, sockeye), and host life stage (A, adult; $F$, fry). Thus, for example, the virus isolated from Malkinskiy Hatchery sockeye adults in 2001 was designated MH01SA. When more than one isolate was generated from sampling the same host population on the same date, individual isolate names included a numerical suffix (e.g. LN03SA-1, LN03SA-2). The isolate from rainbow trout in an experimental hatchery near Moscow (Ryb00TF) was kindly provided by Dr. I. Shchelkunov (AllRussian Research Institute of Freshwater Fishes).

IHNV genetic typing. Genetic typing was conducted on selected Russian IHNV isolates from cultured or wild adult and young sockeye salmon from the watershed of the Bolshaya River (Table 3). Viral supernatant prepared as described above was used as a template for reverse-transcriptase polymerase chain amplification (RT-PCR) and nucleotide sequencing of the midG and 5 ' $\mathrm{N}$ regions of the viral genome (Garver et al. 2003, Troyer \& Kurath 2003). Raw sequence data were edited using Sequencher 4.1 software (Gene Codes), and sequence files were aligned and analyzed with MacVector 6.5.3 and AssemblyLIGN 1.0/9 software (International Biotechnologies). The 303 nt midG sequences are homologous to nt 686-988 of the IHNV $\mathrm{G}$ gene sequence in GenBank accession no. U50401, and the 412 nt 5'N sequences are homologous to nt 1-412 of the IHNV $N$ gene sequence in GenBank accession no. U50402.

Phylogenetic analyses were done with PAUP* version 4.0b (Swofford 1998) using 1000 bootstrapped replicates of the infile data. Russian IHNV midG and 5 'N sequences were analyzed in the context of North American IHNV sequences in the GB37 data set (Kurath et al. 2005). Phylogenetic trees (see Fig. 2) are neighbor-joining phylograms with branch lengths accurately indicating genetic distance, and all nodes with bootstrap values less than 70 have been collapsed to polytomies. Trees were drawn using the SRCV isolate of IHNV as the outgroup.

\section{RESULTS}

\section{Isolation of IHNV in hatchery salmonids from Kamchatka}

Virological examination of fry and fingerlings cultured at the 5 hatcheries on Kamchatka Peninsula (Fig. 1) has been done annually since 1996, and the spawning adult fish used for reproduction at the hatch-

Table 3. Russian IHNV isolates characterized by genetic typing. Isolate names are as described in the methods. MidG and 5 ' $\mathrm{N}$ sequence types are shown as universal sequence designations from the IHNV database of the Western Fisheries Research Center (E. J. Emmenegger \& G. Kurath unpubl.)

\begin{tabular}{|c|c|c|c|c|c|c|}
\hline Isolate name & Site of origin & $\begin{array}{l}\text { Isolation } \\
\text { month/year }\end{array}$ & $\begin{array}{l}\text { Host, } \\
\text { life stage }\end{array}$ & Notes & $\begin{array}{l}\text { MidG } \\
\text { type }\end{array}$ & $\begin{array}{l}5{ }^{\prime} \mathrm{N} \\
\text { type }\end{array}$ \\
\hline Ryb00TF & $\begin{array}{l}\text { Rybnoe } \\
\text { Hatchery }\end{array}$ & $4 / 2000$ & $\begin{array}{l}\text { Trout } \\
\text { fry }\end{array}$ & Epidemic in experimental trout hatchery & mG142U & $5 \mathrm{~N} 048 \mathrm{U}$ \\
\hline MH01SA & $\begin{array}{l}\text { Malkinskiy } \\
\text { Hatchery }\end{array}$ & $9 / 2001$ & $\begin{array}{l}\text { Sockeye } \\
\text { adult }\end{array}$ & First IHNV isolation in Kamchatka & mG143U & $5 \mathrm{~N} 001 \mathrm{U}^{\mathrm{a}}$ \\
\hline MH02SF & $\begin{array}{l}\text { Malkinskiy } \\
\text { Hatchery }\end{array}$ & $2 / 2002$ & $\begin{array}{l}\text { Sockeye } \\
\text { fry }\end{array}$ & Epidemic in progeny of $9 / 2001$ adults & $\mathrm{mG} 002 \mathrm{U}^{\mathrm{a}}$ & $5 \mathrm{~N} 049 \mathrm{U}$ \\
\hline MH02SA & $\begin{array}{l}\text { Malkinskiy } \\
\text { Hatchery }\end{array}$ & $9 / 2002$ & $\begin{array}{l}\text { Sockeye } \\
\text { adult }\end{array}$ & Same host stock as MH01SA & mG143U & $5 \mathrm{~N} 001 \mathrm{U}^{\mathrm{a}}$ \\
\hline OH01SA & $\begin{array}{l}\text { Ozerki } \\
\text { Hatchery }\end{array}$ & $9 / 2001$ & $\begin{array}{l}\text { Sockeye } \\
\text { adult }\end{array}$ & Second IHNV isolation in Kamchatka & $\mathrm{mG} 003 \mathrm{U}^{\mathrm{a}}$ & $5 \mathrm{~N} 001 \mathrm{U}^{\mathrm{a}}$ \\
\hline LN03SA-1 & $\begin{array}{l}\text { Lake } \\
\text { Nachikinskoe }\end{array}$ & $7 / 2003$ & $\left.\begin{array}{c}\text { Sockeye } \\
\text { adult }\end{array}\right)$ & 3 different 5 -fish pooled samples collected & $\mathrm{mG} 144 \mathrm{U}$ & $5 \mathrm{~N} 050 \mathrm{U}$ \\
\hline LN03SA-2 & $\begin{array}{l}\text { Lake } \\
\text { Nachikinskoe }\end{array}$ & $7 / 2003$ & $\begin{array}{l}\text { Sockeye } \\
\text { adult }\end{array}$ & $\begin{array}{l}\text { on the same date from wild fish at their } \\
\text { natural spawning ground }\end{array}$ & $\mathrm{mG} 003 \mathrm{U}^{\mathrm{a}}$ & $5 \mathrm{~N} 001 \mathrm{U}^{\mathrm{a}}$ \\
\hline LN03SA-3 & $\begin{array}{l}\text { Lake } \\
\text { Nachikinskoe }\end{array}$ & $7 / 2003$ & $\begin{array}{l}\text { Sockeye } \\
\text { adult }\end{array}$ & & mG144U & $5 \mathrm{~N} 050 \mathrm{U}$ \\
\hline
\end{tabular}




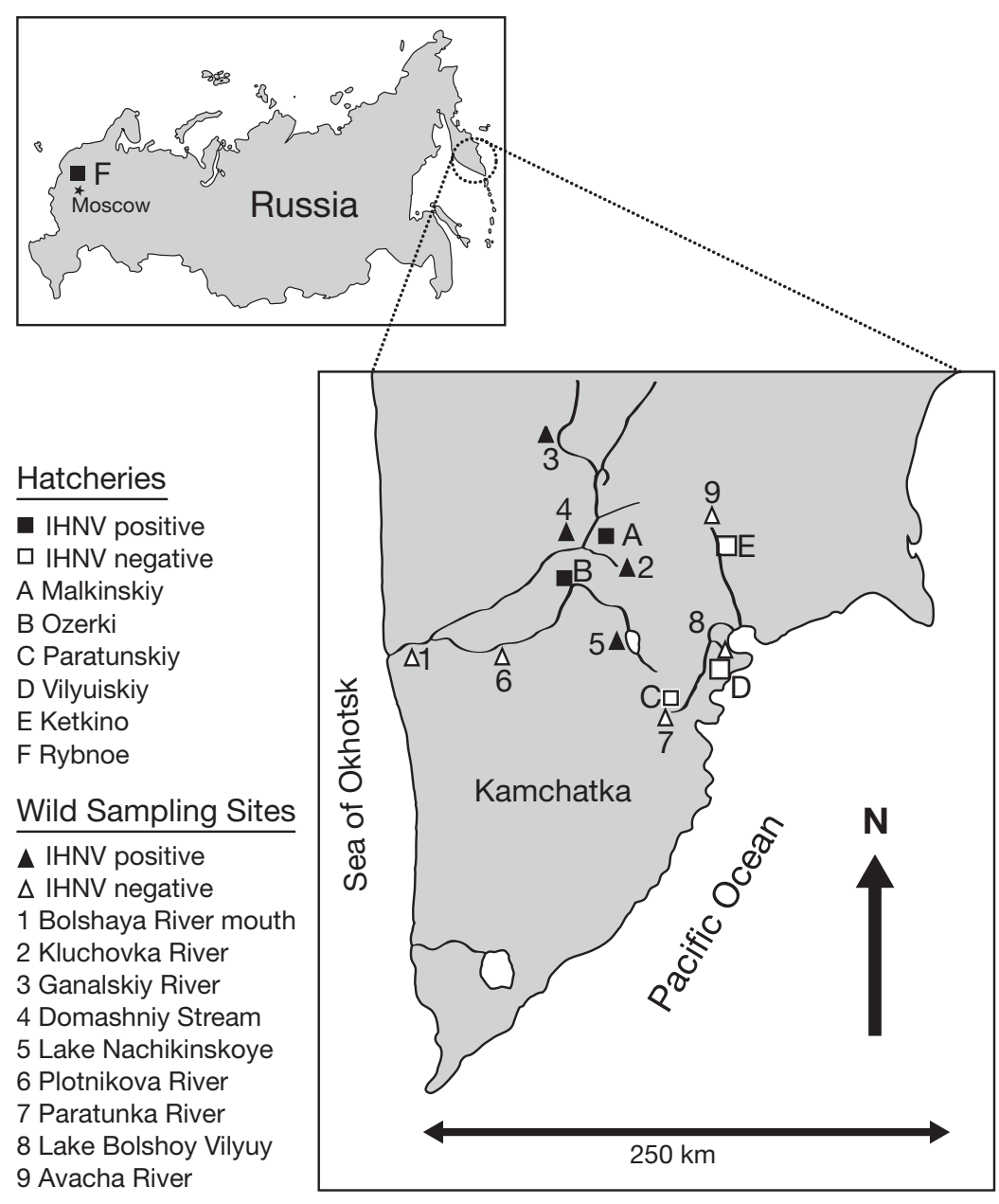

Fig. 1. Southern end of the Kamchatka Peninsula indicating the collection sites for Russian salmon examined for presence of IHNV

eries have been examined annually since 2000 (Table 1). In cultured populations of young or adult chum, coho, and chinook salmon, no IHN virus was detected during 1996 to 2005, although cytoplasmic inclusions tentatively indicating viral erythrocytic necrosis (VEN) or erythrocytic inclusion body syndrome (EIBS) were occasionally observed (S. Rudakova unpubl. data). The first confirmed IHNV detection in Kamchatka occurred in sockeye salmon hatchery adults in 2001 (Rudakova 2004, Rudakova \& Bochkova 2005).

In September 2001, 30 adult sockeye salmon returning to each of the 2 streams near Malkinskiy and Ozerki hatcheries were examined, and IHNV was detected in 50 and $75 \%$ of the fish, respectively. These fish were used as brood stock at the Malkinskiy and Ozerki salmon hatcheries, and their eggs were disinfected after fertilization in $0.1 \%$ active iodine for 15 min. Upon positive identification of IHNV in the adult broodstock, the disinfection was repeated at the eyed-egg stage. An epidemic of IHN occurred from
February through April 2002, only at the Malkinskiy hatchery, among 5 to $6 \mathrm{~cm}$ progeny (age 60 to $90 \mathrm{~d}$ ) (Rudakova 2004). Cumulative percent mortality was $79 \%$ at the point when the remaining fish were destroyed in order to avoid further contagion. External signs were typical for this disease (Wolf 1988).

Due to this first detection of IHNV, more extensive testing of the sockeye broodstock at the Malkinskiy and Ozerki salmon hatcheries was done in 2002 to 2005, and virus was detected at both facilities. At the Malkinskiy Hatchery, prevalence and individual fish virus titers increased with time during the spawning season from $16.6 \%$ to $66.7 \%$ in 2002 and from $66.7 \%$ to $83.3 \%$ in 2003 (Rudakova \& Bochkova 2005). At the Ozerki Hatchery, IHNV was not detected among adult sockeye in 2002 but prevalence of IHNV-positive fish was $50 \%$ in 2003. A second epidemic of IHNV occurred from March to June 2004 among 3 to $5 \mathrm{~cm}$ (age 20 to $90 \mathrm{~d}$ ) sockeye progeny reared at the Ozerki Hatchery. Mortality was $48 \%$, and all fish from infected lots were destroyed to avoid further contagion. In 2004, sockeye used for reproduction at the 2 hatcheries were examined during the spawning season, and the prevalence of IHNV was $16.6 \%$ at the Ozerki Hatchery and $16.6 \%$ at the Malkinskiy Hatchery. In 2005, sockeye broodstocks were IHNV positive only at the Malkinskiy Hatchery, with a prevalence of $6.9 \%$ by testing of individual fish.

In all cases of positive virus diagnosis, typical IHNVinduced CPE (Meyers 2000) was observed in cell lines between 3 and 6 d post-inoculation (PI), and destruction of the cell monolayer was nearly complete at all dilutions by $10 \mathrm{~d}$ PI. The presence of IHNV was confirmed from each of these cell cultures by using the serum neutralization assay (LaPatra 1994). The titer of IHNV varied from $10^{6}$ to $10^{9} \mathrm{TCID}_{50} \mathrm{ml}^{-1}$.

\section{Isolation of IHNV in wild salmonids from Kamchatka}

The examination of wild populations of salmon in watersheds of Kamchatka began in 1997, but inspections were not systematic until after 2000, when sampling became more regular (Table 2). IHNV can be isolated most easily during epidemics among young 
fish or at the end of the fish life cycle during spawning (Mulcahy et al. 1982). For this reason, adult fish were caught on their natural spawning grounds for sampling. Due to detection of IHNV in adult hatchery sockeye in 2001, a more extensive survey of wild fish, including spawning sockeye, was conducted in 2002 to 2005 at 6 sites in the Bolshaya River watershed: mouth of the Bolshaya River, Kluchovka River, Ganalskiy Vahtang River, Domashniy stream, Lake Nachikinskoe, and Plotnikova River. Wild fish were also sampled from 2 other independent watersheds: Avacha River and Paratunka River (including Bolshoy Viljuy Lake). These watersheds contain the Ketkino, Paratunskiy, and Viljuskiy hatcheries (Fig. 1; Table 3). In wild populations of adult and juvenile chum, coho, pink salmon, and Salvelinus malma, no IHNV was detected during this period of observation (Table 2). IHNV was found in adult sockeye from 3 of the 6 sampling sites within the Bolshaya River watershed, including the Ganalskiy Vahtang River, Domashniy stream, and Lake Nachikinskoe. Sockeye fry were also IHNV positive in Lake Nachikinskoe. In this lake, a natural epidemic was ongoing among sockeye fry, and the histopathology of collected fish was consistent with IHNV infection. This is the first confirmation of an epidemic of IHN in wild salmon in Russia, as this sockeye population has never been supplemented with hatchery fish.

As above, in all cases, typical IHN-induced CPE (Meyers 2000) was observed in cell lines between 3 and $6 \mathrm{~d}$ PI, destruction of the cell monolayer was nearly complete at all dilutions by $10 \mathrm{~d}$ PI, and IHNV was confirmed by serum neutralization assay (LaPatra 1994). The titer of the virus was quite high $\left(10^{6}\right.$ to $\left.10^{9} \mathrm{TCD}_{50} \mathrm{ml}^{-1}\right)$.

\section{Genetic typing of IHNV from Kamchatka}

Genetic typing of 8 Russian IHNV isolates (Table 3) was done by determining their midG and 5 ' $\mathrm{N}$ nucleotide sequences. Among these isolates were 5 from hatchery fish, including the first confirmed Russian IHNV from Rybnoe in eastern Russia in 2000, and isolates from the Malkinskiy and Ozerki hatcheries in 2001 to 2002. The other 3 isolates were from 3 different 5-fish pools sampled on the same date in 2003 from a wild spawning sockeye salmon population in Lake Nachikinskoe. With the exception of the Rybnoe isolate, all hatchery and wild IHNV isolates that were typed originated in the Bolshaya River watershed in Kamchatka (Fig. 1).

Analyses of the midG sequences from these $8 \mathrm{IHNV}$ isolates revealed 3 pairs of isolates with identical sequences; thus there were 5 unique midG sequences from the Russian isolates (Table 3). Alignment of the 5 unique midG sequence types from Russian IHNV showed 5 sites of sequence variability distributed apparently randomly along the sequence. The sequences differed from each other by 1 to $3 \mathrm{nt}$ out of $303 \mathrm{nt}$, so the maximum pair-wise divergence was $1.0 \%$ (Fig. 2). Among the Russian IHNV, the Ryb00TF isolate from eastern Russia had the most divergence, with 3 nt difference from most other sequences. Excluding this isolate, the Kamchatka IHNV midGs differed by only 0 to 2 nt $(0.7 \%$ maximum divergence). The 3 isolates representing different 5 -fish pooled samples from the wild sockeye in Lake Nachikinskoe had 1 of 2 different consensus sequences, and within 2 of these isolates there was clear sequence heterogeneity in which nucleotide position 21 had 2 peaks indicating both $\mathrm{C}$ and $\mathrm{A}$. Two of the Russian IHNV midG sequence types were identical to common midG sequence types described previously from North American IHNV. The identical midG sequence from Russian isolates OH01SA and LN03SA2 matched the midG sequence type designated mG003U, previously found in 33 IHNV isolates from Alaska, British Columbia, and Washington (Emmenegger \& Kurath 2002, E. J. Emmenegger \& G. Kurath unpubl. data). Similarly, the midG of the Russian MH02SF was identical to sequence type mG002U, which has been found in 57 IHNV isolates, again from Alaska, British Columbia, and Washington (Emmenegger et al. 2000, E. J. Emmenegger \& G. Kurath unpubl. data).

Phylogenetic analyses of the Russian midG sequences combined with midG sequences from $37 \mathrm{IHNV}$ isolates selected to represent all currently known IHNV genetic types (the GB37 database, Kurath et al. 2005) showed all Russian IHNV to be within the major U

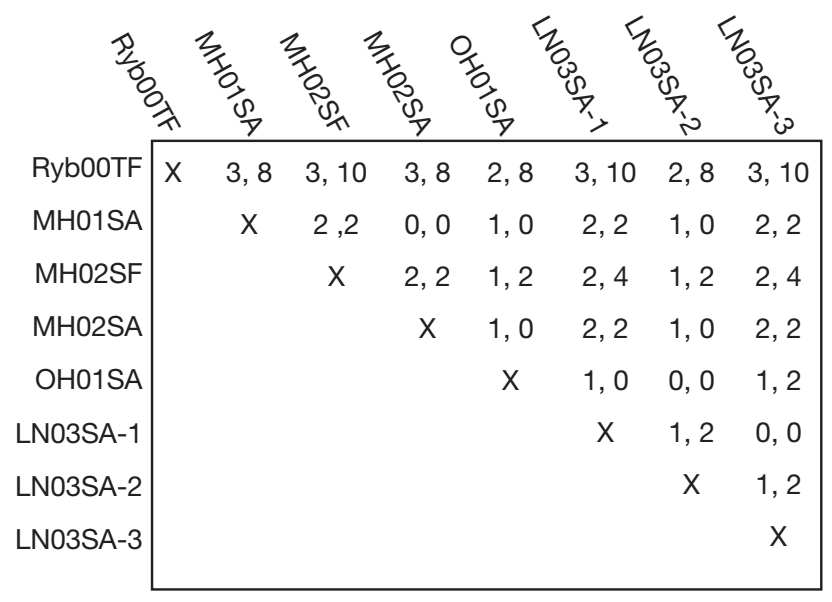

Fig. 2. Number of nucleotide (nt) differences identified among sequences from $8 \mathrm{IHNV}$ isolates obtained from salmonid fish in Russia. Isolate names are as in Table 3, and entries indicate the pair-wise number of nt differences in the midG sequences, followed by the number of nt differences in the $5{ }^{\prime} \mathrm{N}$ sequences 

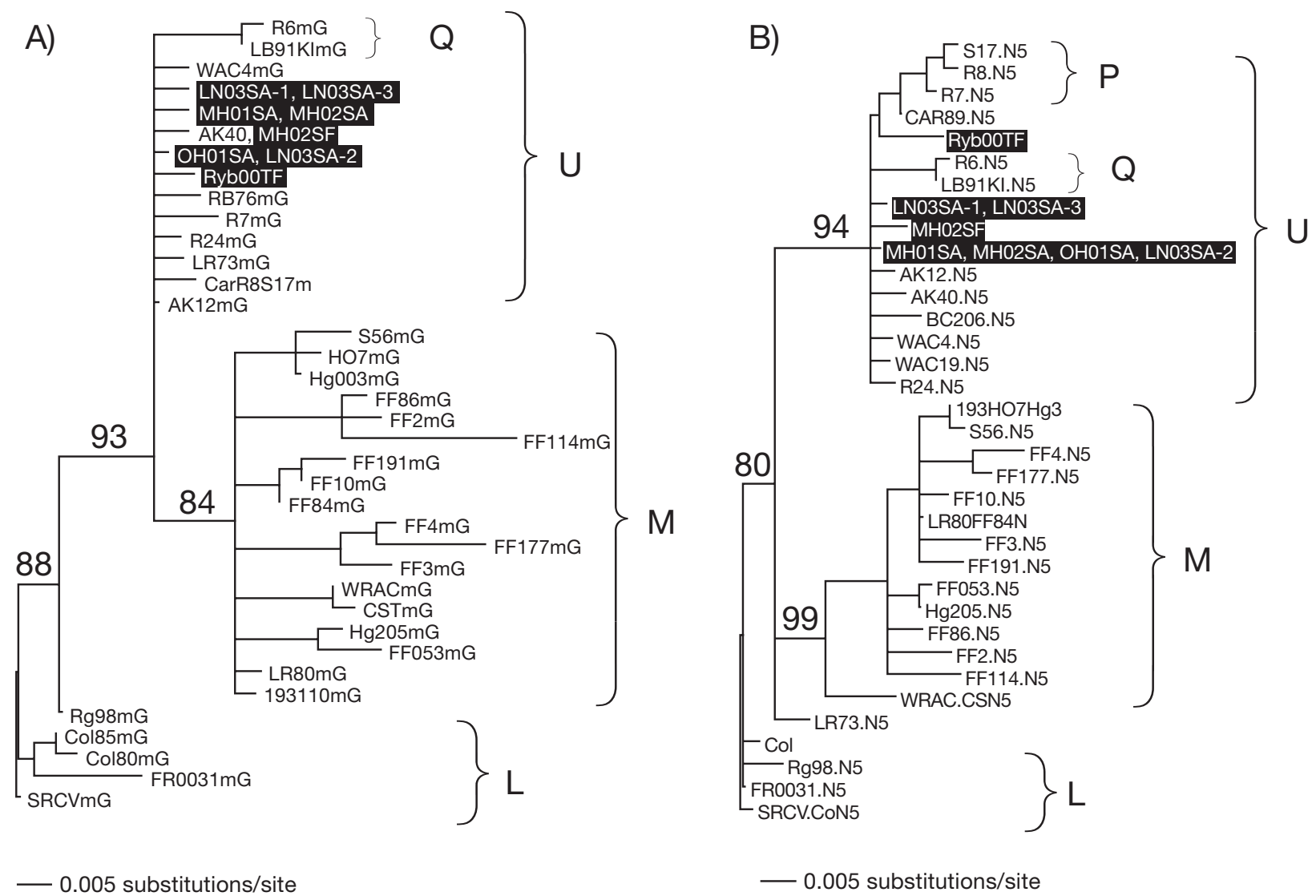

Fig. 3. Phylogenetic analysis of (A) midG and (B) 5'N sequences from 8 IHNV isolates obtained from salmonid fish in Russia. Trees shown are neighbor-joining distance phylograms with horizontal branch lengths accurately corresponding to genetic distance. Bootstrap values from 1000 bootstrap data sets are shown at major nodes, and all branches with values less than 70 have been collapsed to polytomies. Nomenclature for North American sequence types from the GB37 data set are as in Kurath et al. (2005), and Russian isolate names, as in Table 3, are highlighted in black boxes. The known major genogroups (U, M, L) and sub-groups (P, Q) of IHNV are indicated by brackets

genogroup of IHNV (Fig. 3A). The Russian sequences were indistinguishable from North American U genogroup sequences in that they fell on short individual branches from a common ancestral node, with no branching sub-structure. This placement was consistent in phylogenetic trees made with either neighborjoining distance or parsimony algorithms, and in trees with larger databases including all currently known IHNV midG sequences (data not shown).

In phylogenetic analyses of a different gene region, 5 ' $\mathrm{N}$ sequences of IHNV have previously shown more structure within the U genogroup (Garver et al. 2003, Kurath et al. 2005). The 8 Russian IHNV isolates grouped into a total of 4 different $5^{\prime} \mathrm{N}$ sequences that correlated well with the groupings by midG identities (Table 3). The only difference was that 4 Russian isolates had identical 5 ' $\mathrm{N}$ sequences, and these isolates were resolved into 2 pairs of identical isolates by midG analyses. Alignment of the Russian 5 ' $\mathrm{N}$ sequences revealed 13 sites of variability, again distributed along the length of the sequence. The pair-wise differences between $5^{\prime} \mathrm{N}$ sequences ranged from 0 to $10 \mathrm{nt}$ out of $412 \mathrm{nt}$, for a maximum divergence of $2.4 \%$ (Fig. 2). Again the Ryb00TF isolate was most divergent, and when it was excluded, the Kamchatka IHNV $5^{\prime} \mathrm{N}$ sequences differed by only 0 to $4 \mathrm{nt}$ (maximum $1.0 \%$ divergence). The $5^{\prime} \mathrm{N}$ sequence that was identical in 4 of the Russian IHNV isolates matched the $5^{\prime} \mathrm{N}$ sequence type designated 5N001U, which was found in the North American isolate RB76 (Nichol et al. 1995). The other 3 Russian $5^{\prime} \mathrm{N}$ sequence types did not match previously identified sequence types. Sequence heterogeneity among and within the 3 isolates from Lake Nachikinskoe wild spawning sockeye was again evident, with 1 of 2 nucleotides at each of 3 sites: nt 222, 319, and 378.

Phylogenetic analyses of the Russian 5'N sequences combined with the $5^{\prime} \mathrm{N}$ sequences of the GB37 database again showed that all Russian IHNV fell clearly within the U genogroup (Fig. 3B). The Ryb00TF isolate from Eastern Russia appeared to be basal to the sub- 
group U-P within the U genogroup (Kurath et al. 2005), and the Kamchatka isolate types formed short individual branches to the ancestral node, similar to all other North American sequence types. Again, this placement was consistent in trees generated with other algorithms or databases (data not shown).

\section{DISCUSSION}

Observations of fish in Russia for viral pathogens have not been extensive due to the comparatively low level of aquaculture development and long economic crisis in the country. We began to carry out purposeful investigation of both cultured and wild populations of salmon to define prevalence of IHNV in Kamchatka in 2000. Prior to that time, sampling of salmon hatchery fry since 1996 had not detected IHNV. Between 2000 and 2005, over half of the observed populations of sockeye salmon were IHNV positive (Tables 1 \& 2). Although this observation suggests a possible recent increase in IHNV prevalence, we cannot conclude that IHNV was not present prior to 2001. A lack of information does not mean that fish in watersheds are free from viral pathogens. It is very important to know about the presence of virulent pathogens in order to prevent their spread via human activity.

Aquaculture in Kamchatka began in 1926, when the first Kamchatka hatchery opened on Lake Ushkovskoe in the watershed of the Kamchatka River. This hatchery used a spring water supply to rear fry of sockeye, coho, and chum. However, the facility was small and economically unsuccessful, and it was closed at the beginning of the 1980s. Examination of documents about the work of the Ushkovskiy Hatchery during the 1920 s to 1980 s revealed different mortality levels $(3.2$ to $92.1 \%$ ) for fry of all salmon species during all periods of rearing. Managers and scientists have written only about poor fish culture technology or inadequate water supply, and nothing about pathological changes among fish. Hatcheries currently rearing salmon on Kamchatka peninsula are relatively new. The oldest is Malkinskiy Hatchery, which began work in 1982. The other 4 hatcheries were opened in the 1990s. These hatcheries did not use eggs of sockeye or other species of salmon from the USA or other countries.

Historical literature suggests that IHNV in North America was originally restricted to sockeye salmon hosts (Rucker et al. 1953, Guenther et al. 1959, Wingfield et al. 1970), and that the virus was endemic in Alaskan sockeye before it became widespread in more southern states of Washington, Oregon, and California (Amend \& Wood 1972, Grischkowsky \& Amend 1976, Mulcahy et al. 1980). In light of these observations, it is interesting that IHNV in Kamchatka was only found in sockeye salmon and that it is a U genogroup virus very similar to IHNV from northwestern North America. In North America, IHNV may have been inadvertently spread throughout the lower states by the historically common practices of salmon transplantations (Wolf 1988, Roppel 1982, Burgner 1991) and/or use of raw, unpasteurized salmon viscera in feed for salmon fry in hatcheries during the 1950s and 1960s (Watson et al. 1954, Guenther et al. 1959, Wolf 1988). The suggestion that IHNV was introduced to Japan via a shipment of contaminated sockeye salmon eggs from Alaska (Sano et al. 1977) is consistent with the typing of a Japanese IHNV isolate within the U genogroup (Kurath et al. 2003), since all IHNV analyzed to date from Alaska are in the U genogroup (Emmenegger et al. 2000). Similarly, the finding that western European IHNV isolates are all within the M genogroup (Enzmann et al. 2005) agrees with the suggestion that IHNV was introduced to Europe in infected trout eggs from the United States (Bovo et al. 1987, 1991, Laurencin 1987), since rainbow trout in North America have almost exclusively M genogroup IHNV (Troyer et al. 2000, Troyer \& Kurath, 2003).

We do not know what role Kamchatka sockeye play in the global picture of IHNV. Is this virus common in Russian populations of sockeye? Has it been in those host populations for many years or was it recently introduced? It is interesting to consider the possible source of the virus detected since 2001 in Kamchatka sockeye. Russian hatcheries in Kamchatka have never imported eggs or fry from North America or other countries, so we assume the presence of IHNV is due to more natural causes. Many authors (Barnaby 1944, Hartman \& Raleigh 1964, Burgner 1991, Quinn 1993) have described 'homing' for sockeye, and it is highly unlikely that infected American fish stray to Russian rivers to spawn. However, phylogenetic analysis of Russian IHNV isolates presented here showed that they clearly fall within the U genogroup and are very similar, or even identical by our typing methods, to common American isolates from the northern U genogroup range. A basic principle of evolutionary biology is that separation and isolation of distinct populations of a species leads over time to their divergence, either by genetic drift or differing selection in their respective environments. The lack of evolutionary divergence between IHNV in sockeye from Russia and North America suggests that the virus in these 2 host populations comes from a common source relatively recently and/or continuously. This in turn suggests that the source of IHNV is in the Pacific Ocean. The nature of a putative ocean source of IHNV is not known, but possible candidates include salmonid or non-salmonid fishes, parasites, or prey organisms. Groot \& Margolis (1991) have shown that marine migration ranges of Kamchatka and American populations of sockeye 
overlap in the northern Pacific Ocean, so direct transmission of virus between Russian and American sockeye in the ocean could occur. Although this is contrary to the concept that IHNV transmission occurs mostly in fresh water (Bootland \& Leong 1999), recent IHN epidemics among Atlantic salmon Salmo salar reared in marine net-pen farms (Armstrong et al. 1993) confirm that IHNV infections can be transmitted in sea water. In the marine environment, IHNV has been isolated from an adult sockeye salmon (Traxler et al. 1997) and from 3 non-salmonid finfish species (Kent et al. 1998). Additional non-salmonid fishes have been shown to be susceptible to experimental IHNV infection (Castric \& Jeffroy 1991, LaPatra et al. 1995). With regard to possible non-fish sources, Foerster (1968) and French et al. (1976) summarized the stomach analysis data for sockeye reported by various investigators for many different areas of the ocean. The ability of IHNV to reproduce in these prey organisms is unknown. Ectoparasites of sockeye salmon have also been suggested as possible vectors for transfer of IHNV between fish (Mulcahy et al. 1990). At present it is impossible identify the source of the virus in the Pacific Ocean, but results of phylogenetic analysis of Russian and American IHNV isolates suggest either direct transmission between sockeye populations in the ocean, or existence of a non-sockeye seawater reservoir.

In addition to viral reservoirs, the data presented here suggest IHNV host specificity. Despite sampling many salmonid species of both wild and hatchery fish in Kamchatka, IHNV was only isolated from sockeye. In North America, the IHNV that caused the first explosive epidemics in hatchery sockeye during the 1950s did not cause disease in other fish species reared at the same facilities, and it did not cause disease in chinook or rainbow trout in severe experimental challenges (Rucker et al. 1953, Watson et al. 1954). Our current hypothesis is that in North America this first sockeye-specific virus was an ancestral U genogroup virus, and a host jump into rainbow trout may have resulted in divergence of the $\mathrm{M}$ genogroup (Kurath et al. 2003). In the Kamchatka hatcheries, when chum or chinook salmon, at either juvenile or adult life stages, were reared in the same facility as infected sockeye for multiple years they had no detectable virus (Table 1). The U genogroup IHNV in Russia may be sockeyespecific, although this hypothesis requires experimental testing. If true, it would be wise to conduct Russian aquaculture in such a manner as to prevent host jumps to other species. Among the wild salmonids sampled in Kamchatka, sockeye was the only species known to be a common host for IHNV. The other species (pink, chum, coho, and malma) are more refractory to IHNV (Wolf 1988, Bootland \& Leong 1999), and our study confirmed this for Kamchatka.
In the genetic typing data presented here, the low level of divergence observed among the Kamchatka IHNV isolates ( 0 to $2 \mathrm{nt}$ in the midG and 0 to $4 \mathrm{nt}$ in the $5^{\prime} \mathrm{N}$ ) was typical of the diversity seen in U genogroup isolates from North America (Kurath et al. 2003). The underlying concepts suggested previously for homogeneity of North American U genogroup IHNV isolates included high fitness of $\mathrm{U}$ virus in sockeye due to a long established host-pathogen association, and/or continuous direct or indirect exchange of virus among a geographically broad range of host stocks as discussed above. These concepts can now be extended to Russian IHNV. In practical terms, although the genetic homogeneity and the analysis of short genomic regions limits our ability to make conclusions regarding epidemiology within the U genogroup, several interesting observations can be made from the genetic typing data. Among the IHNV isolates characterized here, those with identical sequences came from the same sampling site or from sites within the same sub-basin (Table 3). At Malkinskiy Hatchery, IHNV from the adult sockeye in 2001 and 2002 were identical by our typing methods. However, the IHNV from the 2002 fry epidemic differed from the adult virus isolates by $2 \mathrm{nt}$ in the midG and $2 \mathrm{nt}$ in the $5^{\prime} \mathrm{N}$. Although we must be conservative in our interpretations due to the small number of nucleotide differences involved, this observation suggests that the source of the IHNV that caused the fry epidemic was not the progenitor adults, so alternative sources should also be considered. Another interesting result from the typing data was the sequence difference found within and among virus isolates from wild sockeye in Lake Nachikinskoe. This difference demonstrates detectable genetic heterogeneity within the virus population circulating in one wild host population at the same time, but not necessarily within an individual fish, because the samples were 5 -fish pools. As a third point, it is worth considering the possible origin of the Rybnoe isolate from a trout hatchery in eastern Russia. This isolate appeared uniquely divergent from the IHNV in Kamchatka, and it is not likely to be from western Europe because all European IHNV characterized to date are in the M genogroup (Enzmann et al. 2005). Although the original source is unknown, the Rybnoe isolate may represent IHNV endemic in a region of Russia other than Kamchatka. Finally, from a phylogenetic standpoint, the data presented here show no evidence of a monophyletic origin of IHNV in Kamchatka, or in Russia in general. This differs from IHNV from western Europe, which appeared to comprise a monophyletic group within the M genogroup (Enzmann et al. 2005). It may be that the phylogenetic analyses presented here cannot resolve a common ancestor for Russian IHNV due to the short genome regions analyzed and the low 
genetic diversity in the U genogroup. Alternatively, the absence of a common ancestor is consistent with the hypothesis that the presence of IHNV in Kamchatka is not due to an introduction from a North American source, but rather that it represents an endemic virus and that Kamchatka is part of a larger contiguous geographic range of the U genogroup.

In the data presented here, IHNV was found in both hatchery and wild sockeye, but only in 1 of the 3 large watersheds where sampling was conducted. In the future, it will be important to survey IHNV from a wide range of Russian salmon populations to develop a more thorough understanding of the prevalence patterns, host specificity, and genetic types of the virus in Russia. This survey will determine whether the virus is limited to sockeye and to the Bolshaya watershed, and provide essential information for mitigating the disease impacts that have occurred in Kamchatka sockeye since 2001 .

Acknowledgements. The authors thank Dr. I. Shchelkunov for generously providing isolate Ryb00TF, J. Kaufman for providing IHNV-specific antisera, and J. Ranson for assistance with graphics. We also very deeply appreciate the important contributions of the managers of each of the Kamchatka fish hatcheries where we obtained samples, L. V. Saharovskyju and A. P. Gorban. Finally, we sincerely thank the directors of our institutes, Dr. N. P. Antonov and Dr. L. Thorsteinson, for providing support for S.L.R. as a visiting scientist at the Western Fisheries Research Institute.

\section{LITERATURE CITED}

Amend DF, Wood JW (1972) Survey for infectious hematopoietic necrosis (IHN) virus in Washington salmon. Prog Fish Cult 34:143-147

Amend DF, Yasutake WT, Mead RW (1969) A hematopoietic virus disease of rainbow trout and sockeye salmon. Trans Am Fish Soc 98:796-804

Armstrong R, Robinson J, Rymes C, Needham T (1993) Infectious hematopoietic necrosis in Atlantic salmon in British Columbia. J Can Vet 34:312-313

Barnaby JT (1944) Fluctuations in abundance of red salmon, Oncorhynchus nerka (Walbaum), of the Karluk River, Alaska. US Fish Wildl Serv Spec Sci Bull 50:237-295

Bovo G, Giorgetti G, Jorgensen PEV, Nelson NJ (1987) Infectious hematopoietic necrosis: first detection in Italy. Bull Eur Assoc Fish Pathol 7:124

Bovo G, Ceschia G, Giorgetti G (1991) Infectious hematopoietic necrosis: situation after 3 years from the first outbreak in Italy. Bolletino Soc Ital Patol Ittica 5:31-36

Bootland LM, Leong JC (1999) Infectious hematopoietic necrosis virus. In: Woo PTK, Bruno DW (eds) Fish diseases and disorders, Vol 3. CAB International, Oxfordshire, p 57-112

Burgner RL (1991) Life history of sockeye salmon (Oncorhynchus nerka). In: Groot C, Margolis L (eds) Pacific salmon life histories. UBC Press, Vancouver, p 1-118

Castric J, Jeffroy J (1991) Experimentally induced diseases in marine fish with IHNV and a rhabdovirus of eel. In: Aquaculture and the environment. Eur Aquacult Soc Spec Publ 14, Bredene, Belgium, p 54-55
Emmenegger EJ, Kurath G (2002) Genetic characterization of infectious hematopoietic necrosis virus of coastal salmonid stocks in Washington State. J Aquat Anim Health 14:25-34

Emmenegger RJ, Meyers TR, Burton TO, Kurath G (2000) Genetic diversity and epidemiology of infectious hematopoietic necrosis virus in Alaska. Dis Aquat Org 40: 163-176

Enzmann PJ, Kurath G, Fichtner D, Bergmann SM (2005) Infectious hematopoietic necrosis virus: monophyletic origin of European IHNV isolates from North American genogroup M. Dis Aquat Org 66:187-195

Fijan N, Sulimanovic D, Bearzotti M, Muzinic D, Zwillenberg LO, Chilmonczyk S, Vautherot JF, de Kinkelin P (1983) Some properties of the epithelioma papulosum cyprini (EPC) cell line from carp Cyprinus carpio. Ann Virol (Institut Pasteur) 134:207-220

Foerster RE (1968) The sockeye salmon, Oncorhynchus nerka. Bull Fish Res Board Can 162:422

French R, Bilton H, Osako M, Hartt A (1976) Distribution and origin of sockeye salmon (Oncorhynchus nerka) in offshore waters of the North Pacific Ocean. Int North Pac Fish Comm Bull 34:113

Fried MP (1984) Laboratory technique in virology. Alaska Department of Fish and Game, Division of Fisheries Rehabilitation, Enhancement and Development, Anchorage, AK

Garver KA, Troyer RM, Kurath G (2003) Two distinct phylogenetic clades of infectious hematopoietic necrosis virus overlap within the Columbia River basin. Dis Aquat Org 55: 187-203

Grischkowsky RS, Amend DF (1976) Infectious hematopoietic necrosis virus, prevalence in certain Alaskan sockeye salmon, Oncorhynchus nerka. J Fish Res Board Can 33: 186-188

Groot C, Margolis L (1991) Pacific salmon life histories. Gov Canada, Department of Fisheries and Oceans, Vancouver

Guenther RW, Watson SW, Rucker RR (1959) Etiology of sockeye salmon 'virus' disease. US Fish Wildl Serv Spec Sci Rep Fish 296:1-10

Hartman WL, Raleigh RF (1964) Tributary homing of sockeye salmon at Brooks and Karluk Lakes, Alaska. J Fish Res Board Can 21:485-504

Kent ML, Traxler GS, Kieser D, Richard J and 5 others (1998) Survey of salmonid pathogens in ocean-caught fishes in British Columbia, Canada. J Aquat Anim Health 10: 211-219

Kurath G, Garver KA, Troyer RM, Emmenegger EJ, EinerJensen K, Anderson ED (2003) Phylogeography of infectious hematopoietic necrosis virus in North America. J Gen Virol 84:803-814

Kurath G, Garver KA, Batts WN, Emmenegger EJ (2005) Genetic typing of infectious hematopoietic necrosis virus. In: Cipriano RC, Shchelkunov IS, Faisal M (eds) Health and diseases of aquatic organisms: bilateral perspectives. Michigan State University, East Lansing, MI, p 195-206

LaPatra SE (1994) Infectious hematopoietic necrosis virus. In: Thoesen JC (ed) Suggested procedures for the detection and identification of certain finfish and shellfish pathogens, 4th edn, Virology section, subsection V. American Fisheries Society, Fish Health Section, Bethesda, MD

LaPatra SE, Jones GR, Lauda KA, McDowell TS, Schneider R, Hedrick RP (1995) White sturgeon as a potential vector of infectious hematopoietic necrosis virus. J Aquat Anim Health 7:225-271

Laurencin FB (1987) IHN in France. Bull Eur Assoc Fish Pathol 7:104

Meyers TR (2000) Fish pathology section laboratory manual, 2nd edn. Spec Publ No. 12, Alaska Department of Fish and Game, Commercial Fisheries Division, Anchorage, AK 
Mulcahy DM, Tebbit GL, Groberg WJ, McMichael JS and 5 others (1980) The occurrence and distribution of salmonid viruses in Oregon. Technical Pap No. 5504, ORESU-T-80-004, Oregon Agricultural Experiment Station, Corvallis, OR

Mulcahy D, Burke J, Pascho R, Jenes CK (1982) Pathogenesis of infectious hematopoietic necrosis virus in adult sockeye salmon (Oncorhynchus nerka). Can J Fish Aquat Sci 39: $1144-1149$

Mulcahy D, Klaybor D, Batts WN (1990) Isolation of infectious hematopoietic necrosis virus from a leech (Piscicola salmositica) and a copepod (Salmincola sp.), ectoparasites of sockeye salmon Oncorhynchus nerka. Dis Aquat Org 8: $29-34$

Musselius VA (1983) Laboratory manual on fish diseases. Food Industry Publishing, Moscow

Nichol ST, Rowe JE, Winton JR (1995) Molecular epizootiology and evolution of the glycoprotein and non-virion protein genes of infectious hematopoietic necrosis virus, a fish rhabdovirus. Virus Res 38:159-173

Quinn TP (1993) A review of homing and straying of wild and hatchery-produced salmon. Fish Res 18:29-44

Roppel P (1982) Alaska salmon hatcheries 1891-1959. Alaska Hist Comm Stud No. 20, Library of Congress \#82-600591

Rucker RR, Whipple WJ, Parvin JR, Evans CA (1953) A contagious disease of salmon possibly of virus origin. US Fish Wildl Serv Fish Bull 54:35-46

Rudakova SL (2004) Analysis of epizootic development of infectious hematopoietic necrosis among fry of sockeye salmon Oncorhynchus nerka (Walbaum) reared at the hatchery (Kamchatka). J Probl Fish 5:362-374

Rudakova SL, Bochkova EV (2005) Isolation of infectious hematopoietic necrosis virus (IHNV) from adult sockeye salmon (Oncorhynchus nerka) in Kamchatka. In: Cipriano RC, Shchelkunov IS, Faisal M (eds) Health and diseases of

Editorial responsibility: Julie Bebak, Auburn, Alabama, USA aquatic organisms: bilateral perspectives. Michigan State University, East Lansing, MI, p 248-256

Sano $T$, Nishimura $T$, Okamoto N, Yamazaki $T$, Hanada $H_{\text {, }}$ Watanabe Y (1977) Studies on viral diseases of Japanese fish - VI. Infectious hematopoietic necrosis (IHN) of salmonids in the mainland of Japan. J Tokyo Univ Fish 63:81-85

Swofford DL (1998) PAUP* Phylogenetic Analysis Using Parsimony (*and Other Methods), Version 4. Sinauer Associates, Sunderland, MA

Traxler GS, Roome JR, Lauda KA, LaPatra S (1997) Appearance of infectious hematopoietic necrosis virus (IHNV) and neutralizing antibodies in sockeye salmon Oncorhynchus nerka during their migration and maturation period. Dis Aquat Org 28:31-38

Troyer RM, LaPatra S, Kurath G (2000) Genetic analyses reveal unusually high diversity of infectious hematopoietic necrosis virus in rainbow trout aquaculture. J Gen Virol 81: $2823-2832$

Troyer RM, Kurath G (2003) Molecular epidemiology of infectious hematopoietic necrosis virus reveals complex virus traffic and evolution within southern Idaho aquaculture. Dis Aquat Org 55:175-185

Watson SW, Guenther RW, Rucker RR (1954) A virus disease of sockeye salmon, interim report. US Fish Wildl Serv Spec Sci Rep Fish 138:1-36

Wingfield WH, Fryer JL, Pilcher KS (1969) Properties of the sockeye salmon virus (Oregon strain). Proc Soc Exp Biol Med 130:1055-1059

Wingfield WH, Nims L, Fryer JL, Pilcher KS (1970) Species specificity of the sockeye salmon virus (Oregon strain) and its cytopathic effects in salmonid cell lines. In: Snieszko SF (ed) A symposium on diseases of fishes and shellfishes. American Fisheries Society, Washington, DC, p 319-326

Wolf K (1988) Fish viruses and fish viral diseases. Cornell University Press, Ithaca, NY

Submitted: July 6, 2006; Accepted: January 22, 2007 Proofs received from author(s): March 27, 2007 